\title{
Myxomycetes from mangroves: species occurring in the state of Maranhão, northeastern Brazil
}

\author{
L. A. N. N. Agra ${ }^{a *}$, A. C. C. Bezerra a and L. H. Cavalcanti \\ aLaboratório de Myxomycetes, Departamento de Botânica, Centro de Ciências Biológicas, \\ Universidade Federal de Pernambuco - UFPE, Av. Prof. Moraes Rego, s/n, CEP 50670-901, Recife, PE, Brazil \\ *e-mail: nevesagra@gmail.com
}

Received: June 23, 2014 - Accepted: July 29, 2014 - Distributed: November 30, 2015

(With 2 figures)

\begin{abstract}
Mangrove swamps and forests cover over $137,000 \mathrm{~km}^{2}$ distributed latitudinally among subtropical zones, $7 \%$ of which are in Brazil, with a greater density in the country's northernmost region. Considering that the community of Myxomycetes recorded for this environment is hardly known, three areas located in the state of Maranhão were investigated. Two field trips were conducted, one at the beginning of the rainy season and another during the dry season. In each area, two plots $\left(125 \mathrm{~m}^{2}\right)$ equidistant $100 \mathrm{~m}$ apart from each other were surveyed. In these areas, standing dead tree trunks and dead branches still attached to the mother plant that were above the tideline, were examined. On these same occasions, samples of the aerial litter and from the cortex of living trees (Rhizophora) were collected for the preparation of moist chambers cultures. Twenty-one specimens were obtained from field and moist chambers, belonging to 11 species, distributed in nine genera and five families. Seven species are new records from Maranhão. There was a predominance of r-strategist (73\%) over K-strategist (27\%) species. Cribraria violacea, Comatricha tenerrima, Echinostelium minutum, and Fuligo septica are new worldwide records from mangrove environments, and Oligonema flavidum is reported for the first time from Brazil.
\end{abstract}

Keywords: Myxobiota, mangrove swamps, Oligonema, Rhizophora, microhabitat.

\section{Myxomycetes em manguezais: espécies ocorrentes no estado do Maranhão, nordeste do Brasil}

\section{Resumo}

Os manguezais ocupam mais de $137.000 \mathrm{~km}^{2}$, distribuídos latitudinalmente entre as zonas subtropicais e $7 \%$ encontra-se no Brasil, com maior densidade entre os estados do Pará e Maranhão, na região norte do país. Considerando que a comunidade de mixomicetos registrada para este ambiente é pouco conhecida, três áreas localizadas no estado do Maranhão foram investigadas. Duas excursões foram realizadas, uma no início da estação chuvosa e outra na estiagem. Em cada área, foram georeferenciadas e exploradas duas parcelas $\left(125 \mathrm{~m}^{2}\right)$ equidistantes $100 \mathrm{~m}$ uma da outra foram avaliadas. Nestas, foram explorados troncos mortos em pé e galhos mortos ainda presos à planta-mãe, acima da linha da maré. Nas mesmas ocasiões foram coletadas amostras de folhedo aéreo e córtex de árvores vivas (Rhizophora) para montagem de câmaras-úmidas. Foram obtidos 21 espécimes de campo e câmara-úmida, pertencentes a 11 espécies, distribuídas em nove gêneros e cinco famílias. Sete espécies são novos registros para o Maranhão. Predominaram espécies r-estrategistas (73\%), e 27\% K-estrategistas. Cribraria violacea, Comatricha tenerrima, Echinostelium minutum e Fuligo septica são novos registros para o ambiente de manguezal, e Oligonema flavidum é registrada pela primeira vez no Brasil.

Palavras-chave: Myxobiota, manguezal, Oligonema, Rhizophora, micro-habitat.

\section{Introduction}

Distributed throughout the world in 118 countries and territories located latitudinally among the planet's subtropical zones, mangrove forests cover an area of approximately $137,760 \mathrm{~km}^{2}$ (Alongi, 2009). About $7 \%$ of the area occupied by this ecosystem is located in Brazil, extending along most of its coast (Giri et al., 2011) and concentrated ( $70 \%$ ) between the states of Pará and Maranhão (Menezes et al., 2008).

The presence of Myxomycetes in a mangrove environment began to be documented by the end of 1960's (Kohlmeyer, 1969), however, the first study to describe these organisms in Brazilian mangrove swamps was only 
conducted early this century (Cavalcanti et al., 2000). Currently, knowledge on the species of Myxomycetes occurring in a mangrove environment in Brazil is restricted to eight publications, two of which regarding only a single species (Bezerra et al., 1999; Cavalcanti et al., 2000, In press; Trierveiler-Pereira et al., 2008; Agra et al., 2010; Damasceno et al., 2009, 2011).

The aim of this study is to widen the knowledge of the species of Myxomycetes that occur in mangrove area, adding new records which were obtained by means of a rapid survey conducted in three mangrove areas in Brazil.

\section{Material and Methods}

A rapid inventory was made in three areas belonging to the continuous mangrove belt between the states of Maranhão and Pará: mangrove $1\left(02^{\circ} 27^{\prime} 11,92^{\prime}\right.$ 'S/ 44 $09^{\circ} 35,05^{\prime}$ 'W), located in neighbornhood of Araçagy, in the municipality of Raposa, on São Luís Island; mangrove 2 ( $02^{\circ} 24^{\prime} 19,47^{\prime \prime}$ S/ 44² 25' 26,78” W) and mangrove $3\left(02^{\circ} 24^{\prime} 08,66^{\prime \prime} \mathrm{S} / 44^{\circ} 23^{\prime} 16,16^{\prime \prime} \mathrm{W}\right)$, located in the municipality of Alcântara (Figures 1 and 2).

Field samples were obtained from two field trips in each area studied ( $6 \mathrm{~h}$ per day), one at the beginning of the rainy season and the other at the beginning of the dry season; in each area, two plots $\left(125 \mathrm{~m}^{2}\right)$ were established, $100 \mathrm{~m}$ equidistant from each other which were georeferenced with the aid of a GPS; in these, decaying tree trunks and dead branches that were still attached to the mother plant above the tideline were investigated in search of plasmodia and sporocarps.

In order to obtain specimens that are usually difficult to see in the field, red mangrove (Rhizophora sp.) samples were collected, 45 from the aerial litter and 50 from the cortex of living trees, to assemble 95 moist chambers cultures (Damasceno et al., 2011). Cultivations were kept to environment luminosity and temperature for three months (Stephenson et al., 2001). Cultivations were considered positive for myxomycetes when plasmodial tracks, sclerotium, plasmodium and/or sporocarps were found.

The specimens obtained in the study were identified based on literature (Martin and Alexopoulos, 1969; Farr, 1976; Lado and Pando, 1997; Mitchell, 2012), and those who were in good condition of conservation were deposited at the UFP herbarium (Universidade Federal de Pernambuco).

\section{Results}

A low percentage (16.84\%) of positive moist chambers was obtained, the majority $(81.25 \%)$ from the cortex of living trees. Only $C$. violacea sporulated in moist chambers assembled with the aerial litter (Table 1).

Twenty-one specimens were obtained (field and moist chambers cultures), belonging to 11 species, nine genera, six families and five of the six orders of Myxomycetes. Two specimens that were obtained directly in the field, both collected in mangrove 3 during the dry season and

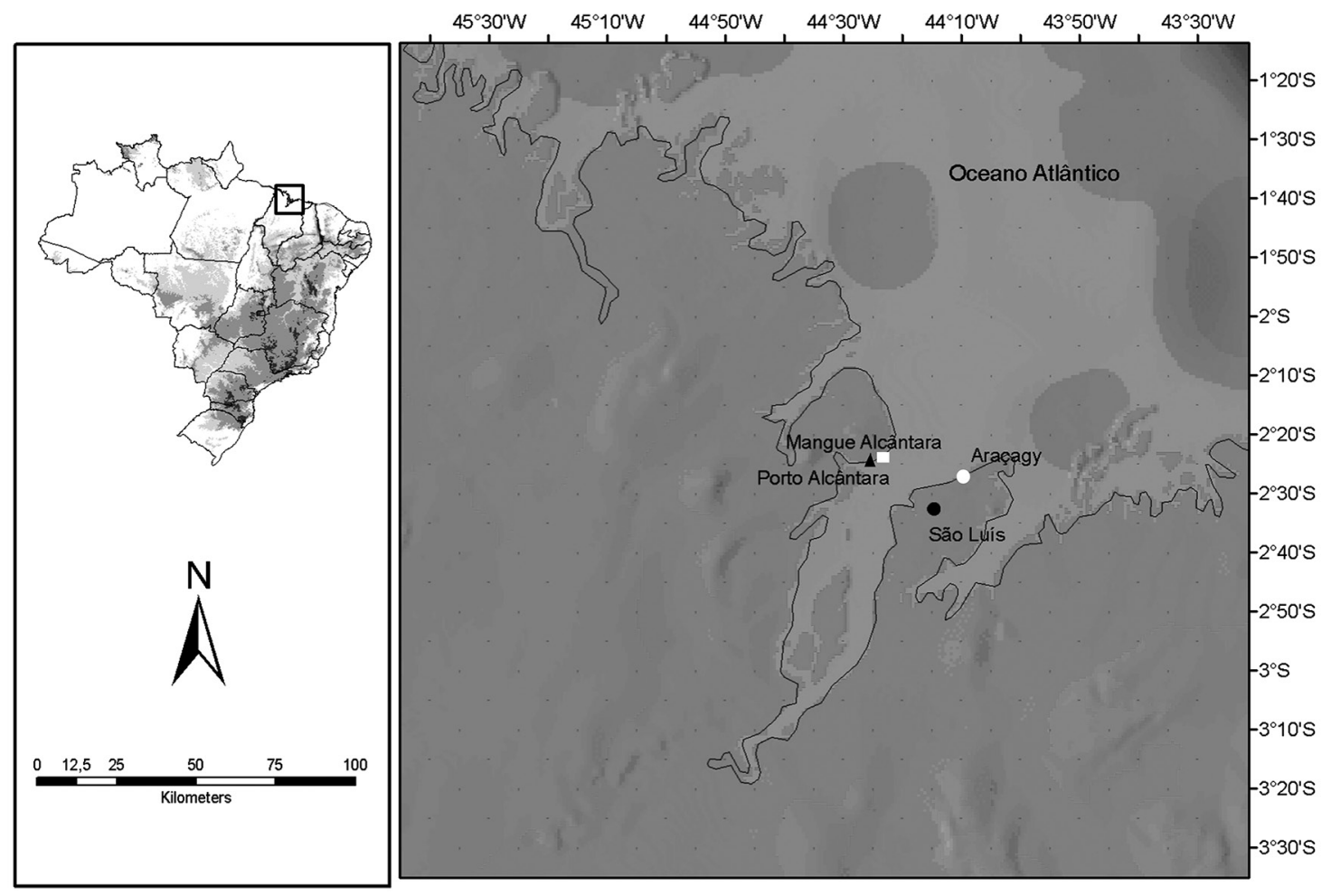

Figure 1. Location of the studied mangroves in the state of Maranhão, Brazil: • Maranhão state capital; ○ mangrove 1; mangrove 2; $\square$ mangrove 3 . 

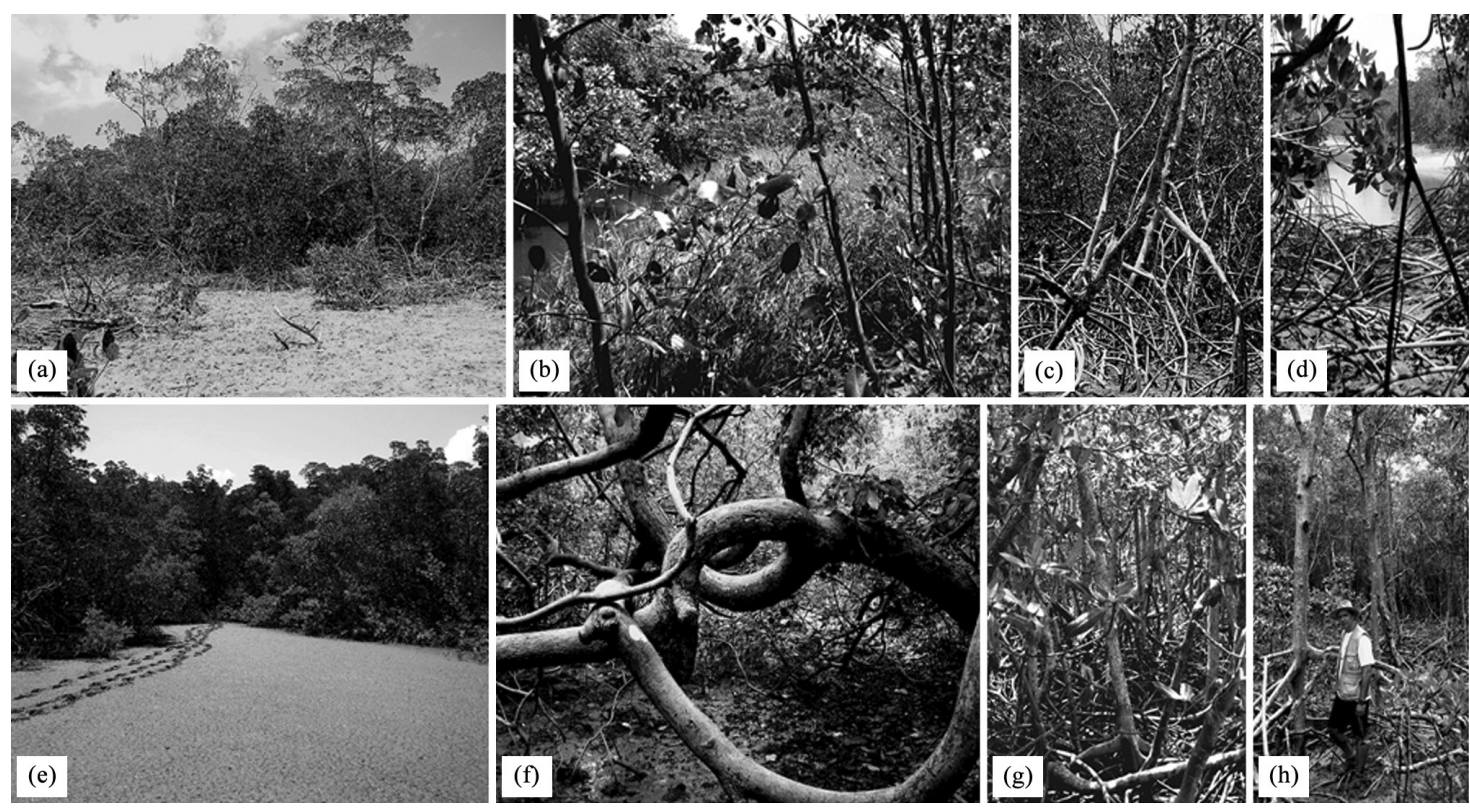

Figure 2. Appearance of the studied mangroves located in the municipalities of Raposa and Alcântara, in Maranhão state, Brazil. a-d: Raposa. e-h: Alcântara.

Table 1. Microhabitats of the species of Myxomycetes recorded on Rhizophora sp. in mangrove areas from the state of Maranhão, Brazil.

\begin{tabular}{lcc}
\hline \multirow{2}{*}{ Species } & \multicolumn{2}{c}{ Microhabitat } \\
\cline { 2 - 3 } & Field & $\begin{array}{c}\text { Moist } \\
\text { chamber }\end{array}$ \\
\hline Collaria arcyrionema & - & Cortex \\
Comatricha tenerrima* & - & Cortex \\
Cribraria confusa & - & Cortex \\
Cribraria violacea* & - & Aerial litter \\
Echinostelium & - & Cortex \\
minutum* & & \\
Fuligo septica* & Dead trunk & - \\
Lycogala epidendrum $^{*}$ & Dead trunk & - \\
Oligonema flavidum $*$ & Dead trunk & - \\
Physarum roseum & - & Cortex \\
Physarum sp. & Dead trunk & - \\
Stemonitis sp. & Dead trunk & - \\
\hline Species with new record from &
\end{tabular}

*Species with new records from mangroves.

on dead tree trunks above the tideline, showed partially destroyed sporocarps (Physarum sp. and Stemonitis sp.). The families which were best represented regarding the number of species were Physaraceae (3 spp.), Stemonitaceae (3 spp.) and Cribrariaceae (2 spp.). Echinosteliaceae, Reticulariaceae and Trichiaceae, were represented by a single species each.

In the mangrove swamps surveyed, myxomycetes occupied different microhabitats, such as those offered by dead branches still attached to the mother plant (five species), on the cortex of living trees (six species) and three species on the aerial litter (Table 1).
Collaria arcyrionema (Rostaf.) Nann.-Bremek. ex Lado, Ruizia 9:26 (1991)

All specimens sporulated in moist chambers, with four samples from mangrove 1 and one from mangrove 2, all from the cortex of living trees. Collaria arcyrionema is well distributed in Brazil (Cavalcanti, 2014), and was reported from mangroves from the state of Pernambuco (Northeastern Brazil) by Damasceno et al. (2011) and Cavalcanti et al. (In press). This is the first record of C. arcyrionema for the state of Maranhão.

Material examined: BRAZIL, Maranhão: Raposa, Araçagy mangrove, corticicolous on Rhizophora, moist chamber, 23 May 2008, leg. Agra L.A.N.N. 339 (UFP); Alcântara, port, corticicolous on Rhizophora sp., moist chamber, 12 Aug 2008, leg. Agra L.A.N.N. 372,377,379 (UFP); corticicolous on Rhizophora sp., moist chamber, 29 Jul 2009, leg. Agra L.A.N.N. 385 (UFP).

Comatricha tenerrima (M.A. Curtis) G. Lister, Guide Brit. Mycetozoa, ed. 439 (1919)

Only two specimens were obtained, both from moist chamber cultivation from the cortex of a living tree in Araçagy. Comatricha tenerrima has rare records in Brazil (Cavalcanti, 2014) and is only found in the Atlantic Forest biome. In literature, there are no records of this specie from a mangrove environment, nor for the state of Maranhão.

Material examined: BRAZIL, Maranhão: Raposa, Araçagy mangrove, corticicolous on Rhizophora sp., moist chamber, 23 May 2008, leg. Agra L.A.N.N. 340 (UFP).

Cribraria confusa Nann.-Bremek. \& Y. Yamam. Proc. Kon. Ned. Akad. Wetensch., C. 86 (2):212 (1983) 
A single specimen, obtained through the cultivation of cortex of a living tree from the municipality of Alcântara, mangrove 2. This is the first record of C. confusa from the state of Maranhão.

Material examined: BRAZIL, Maranhão: Alcântara, port, corticicolous on Rhizophora sp., moist chamber, 09 May 2008, leg. Agra L.A.N.N. 332 (UFP).

Cribraria violacea Rex, Proc. Acad. Nat. Sci. Philadelphia 43:393 (1891)

The three specimens obtained, composed of numerous sporocarps, were developed in moist chambers, one of them sporulating on the aerial litter from mangrove 1 and the other two on the cortex of living trees from mangrove 2 . Well distributed in Brazil (Cavalcanti, 2014), C. violacea is recorded for the first time from a mangrove environment and from the state of Maranhão.

Material examined: BRAZIL, Maranhão: Raposa, Araçagy mangrove, folliicolous on Rhizophora sp., moist chamber, 01 May 2008, leg. Agra L.A.N.N. 311 (UFP); Alcântara, port, corticicolous on Rhizophora sp., moist chamber, 9 May 2008, leg. Agra L.A.N.N. 331 (UFP).

Echinostelium minutum de Bary, in Rostafinski, Sluzowce Monogr. 215 (1874)

The four specimens obtained sporulated in moist chambers assembled with the cortex of living trees collected in mangrove 2. Echinostelium minutum has few records in Brazil, occurring in Caatinga, Cerrado and Atlantic Forest biomes (Cavalcanti, 2014). This is the first record of E. minutum from mangroves and for the state of Maranhão.

Selected material examined: BRAZIL, Maranhão: Alcântara, port, corticicolous on Rhizophora sp., moist chamber, 10 May 2008, leg. Agra L.A.N.N. 337 (UFP).

Fuligo septica (L.) F.H. Wigg., Prim. Fl.Holsat. 112 (1780)

The species is represented by an old aethalium collected directly in the field on mangrove 3 on a dead branch of Rhizophora sp. still attached to the mother plant.

Fuligo septica is widely distributed in Brazil where it has been recorded from the Amazon, Caatinga and Atlantic Forest biomes (Cavalcanti, 2014). Known to occur in the state of Maranhão where it has been recorded on cultivated plants (Silva and Bezerra, 2005; Silva et al., 2008), this species is frequently mentioned in literature for different environments but so far it haven't been recorded from mangroves.

Material examined: BRAZIL, Maranhão: Alcântara, $2^{\circ} 24.147^{\prime} \mathrm{S} / 44^{\mathrm{o}} 23.267^{\prime} \mathrm{W}$, lignicolous on Rhizophora sp., 4 Oct 2009, leg. Agra L.A.N.N. 208 (UFP).

Lycogala epidendrum (L.) Fr., Syst. mycol. 3:80 (1829)
The only specimen obtained was collected directly in the field on a dead branch which was still attached to the mother plant above the tideline. This species was already reported from the Araçagy mangrove by Agra et al. (2010).

Material examined: BRAZIL, Maranhão: Raposa, Araçagy mangrove, lignicolous on Rhizophora mangle, 29 Feb 2008, leg. Agra L.A.N.N. 35 (UFP).

Oligonema flavidum (Peck) Peck, Annual Rep. New York State Mus. 31:42 (1879)

The only specimen obtained, with numerous well-conserved sporocarps, was collected in the field within a preserved area of the Alcântara mangrove 3 on a standing dead tree trunk above the tideline. This is the first record of O. flavidum from mangrove areas and from Brazil.

Material examined: BRAZIL, Maranhão: Alcântara, $2^{\circ}$ 24.147' S/ 44 ${ }^{\circ} 23.267^{\prime}$ W, lignicolous on Rhizophora sp., 4 Octb 2009, leg. Agra L.A.N.N. 205 (UFP).

Physarum roseum Berk. \& Broome, J. Linn. Soc., Bot. 14:84 (1873)

Only a single specimen of $P$. roseum was obtained, sporulated in a moist chamber on the cortex of a trunk from a living tree of Rhizophora sp. in mangrove 2. The developed plasmodium with the typical appearance and coloring of the species produced two types of sporocarps, the first corresponding to the typical form for the species with its stalked sporangium, globose sporotheca umbilicated at the top and the second as a long plasmodiocarp.

Physarum roseum was registered in mangroves from Pernambuco, Cavalcanti et al. (In press), and it is reported for the first time from Maranhão.

Material examined: BRAZIL, Maranhão: Alcântara, port, corticicolous on Rhizophora sp., 29 Sept 2009, moist chamber, leg. Agra L.A.N.N. 386 (UFP).

\section{Physarum sp.}

This specimen was collected directly in the field on a decomposing branch which was still attached to the mother plant in mangrove 3 . The poor condition in which the sporocarps were found only allowed the identification of its genus.

Material examined: BRAZIL, Maranhão: Alcântara, $2^{\circ} 24.147^{\prime} \mathrm{S} / 4^{\circ}{ }^{\circ} 23.267^{\prime} \mathrm{W}$, lignicolous on Rhizophora sp., 4 Octb 2009, leg. Agra L.A.N.N. 306.

\section{Stemonitis sp}

Represented by a single specimen collected directly in the field on a decomposing branch still attached to the mother plant in mangrove 3 . The poor conditions in which the sporocarp was found only enabled the identification of its genus.

Material examined: BRAZIL, Maranhão: Alcântara, $2^{\circ}$ 24.147' S/ 44' 23.267' W, lignicolous on Rhizophora sp., 4 Octb 2009, leg. Agra L.A.N.N. 189. 


\section{Discussion}

With the exception of $C$. arcyrionema, mentioned by Cavalcanti et al. (2000) and Damasceno et al. (2011) from mangroves in the state of Pernambuco, Brazil, the species collected on mangroves of Araçagy and Alcântara are rare in this environment and were represented by only a single specimen. The record of $O$. flavidum mentioned herein widens the types of environments in which it occurs, previously more often reported from temperate forests of the northern and southern hemispheres (Haan et al., 2004; Basanta et al., 2010; Salamaga, 2013).

Daily or seasonal variations in the environment, such as tidal levels in the mangroves or its rainfall regime, select species of myxomycetes that have life strategies which are adequate for such conditions, classifying them as r-strategists or K-strategists (Everhart and Keller, 2008). On mangroves, barks of living trees and aerial litter are microhabitats occupied by $\mathrm{r}$-strategists, while the $\mathrm{K}$-strategists can be found on branches and on dead, decomposing tree trunks fallen on the ground or clinging to the mother plant above the tideline.

On the surveyed mangroves, the majority of the species had r-strategist characteristics, such as $C$. confusa and E. minutum, which are typically corticicolous. Agra et al. (2010), considering characteristics such as fructification size $(<1 \mathrm{~cm})$, long life of plamodium, late maturing, long period of reproduction and production of few and large sporocarps, characterize L. epidendrum as a K-strategist species. For exhibiting similar characteristics and occupying the same microhabitat, $O$. flavidum and F. septica can be classified as K-strategist species.

\section{Acknowledgements}

The authors wish to thank the staff of the Laboratory of Myxomycetes, Federal University of Pernambuco (LABMIX-UFPE), for their field assistance. They also wish to thank the National Council for Scientific and Technological Development (CNPq) for their financial support as scholarships and research grants (proc. 3059/2009-6).

\section{References}

AGRA, L.A.N.N., LEMOS, D.B.N., POWELL, N.V., MEDRADO, W.T. and CAVALCANTI, L.H., 2010. Occurrence of Lycogala epidendrum (Myxomycetes) in a mangrove environment in Brazil. Revista Brasileira de Biociências, vol. 8, no. 2, pp. 164-168.

ALONGI, D.M., 2009. Paradigm shifts in mangrove biology. In: G.M.E. PERILLO, E. WOLANSKI, D.R. CAHOON and M.M. BRINSON, eds. Coastal Wetlands: an integrated ecosystem approach. Amsterdam: Elsevier Science, pp. 615-640.

BASANTA, D.W., LADO, C., ESTRADA-TORRES, A. and STEPHENSON, S.L., 2010. Biodiversity of myxomycetes in subantarctic forests of Patagonia and Tierra del Fuego, Argentina. Nova Hedwigia, vol. 90, no. 1, pp. 45-79. http://dx.doi. org/10.1127/0029-5035/2010/0090-0045.
BEZERRA, A.C.C., BRITO, L.D.B., GUIMARÃES, E. and CAVALCANTI, L.H., 1999. Myxomycetes no manguezal: mixobiota da Reserva Biológica de Santa Isabel, Pacatuba-SE. In: Anais do XI Congresso de Iniciação Científica da UFRPE, 1999, Recife. Recife: UFRPE, pp. 239-242.

CAVAlCANTI, L.H., 2014 [viewed 12 May 2014]. Lista de espécies da flora do Brasil [online]. Rio de Janeiro: Jardim Botânico do Rio de Janeiro. Available from: http://floradobrasil. jbrj.gov.br/jabot/floradobrasil/FB92725

CAVALCANTI, L.H., BEZERRA, A.C.C. and CAMPOS, E.L., 2000. Diversidade da mixobiota de manguezais. In: Mangrove 2000: Sustentabilidade de Estuários e Manguesais, Desenvolvimento e Perspectivas, 2000, Recife. Recife: UFRPE, pp. 44-54.

CAVALCANTI, L.H., DAMASCENO, G., BEZERRA, A.C.C. and COSTA, A.A.A., In press. Mangrove myxomycetes: species occurring on Conocarpus erectus L. (Combretaceae). Sydowia.

DAMASCENO, G., COSTA, A.A.A., PASSAVANTE, J.Z.O. and CAVALCANTI, L.H., 2009. Stemonaria fuscoides (Stemonitaceae, Myxomycetes): a new record for Brazil. Mycotaxon, vol. 108, no. 1, pp. 205-211. http://dx.doi.org/10.5248/108.205.

DAMASCENO, G., TENORIO, J.C.G. and CAVALCANTI, L.H., 2011. Stemonitaceae (Myxomycetes) in Brazilian mangroves. Sydowia, vol. 63, no. 1, pp. 9-22.

EVERHART, S.E. and KELLER, H.W., 2008. Life history strategies of corticolous Myxomycetes: the life cycle, plasmodial types, fruiting bodies, and taxonomic orders. Fungal Diversity, vol. 29 , pp. 1-16.

FARR, M.L., 1976. Myxomycetes. New York: New York Botanical Garden. 304 p. Flora Neotropica Monograph, no. 16.

GIRI, C., OCHIENG, E., TIESZEN, L.L., ZHU, Z., SINGH, A., LOVELAND, T., MASEK, J. and DUKE, N., 2011. Status and distribution of mangrove forests of the world using earth observation satellite data. Global Ecology and Biogeography, vol. 20, no. 1, pp. 154-159. http://dx.doi.org/10.1111/j.14668238.2010.00584.x.

HAAN, M., DE PAUW, S. and BOGAERTS, A., 2004. A study of the genus Oligonema in Belgium. Systematics and Geography of Plants, vol. 74, pp. 251-260.

KOHLMEYER, J., 1969. Ecological notes on fungi in mangrove forests. Transactions of the British Mycological Society, vol. 53, no. 2, pp. 237-250. http://dx.doi.org/10.1016/S0007-1536(69)80058-6.

LADO, C. and PANDO, F., 1997. Flora Mycologica Ibérica. Myxomycetes, 1. Ceratiomyxales. Echinosteliates, Liceales, Trichiales. Madrid: Consejo Superior de Investigaciones Cientificas, Real Jardin Botánico, CSIC.

MARTIN, G.W. and ALEXOPOULOS, C.J., 1969. The Myxomycetes. Iowa: University of Iowa Press.

MENEZES, M.P.M., BERGER, U. and MEHLIG, U.L.F., 2008. Mangrove vegetation in Amazonia: a review of studies from the coast of Pará and Maranhão States, north Brazil. Acta Amazonica, vol. 38, no. 3, pp. 403-420. http://dx.doi.org/10.1590/S004459672008000300004

MITCHELL, D.W., 2012. Myxomycetes. [S.1.]: [s.n.]. CD-ROM of illustrated keys and inventory of all world species. CD for MS Windows. DiKey, dichotomous keys to various groups of 
organsisms. Inventory and synoptic keys of all legitimately described myxomycete taxa. Private publication.

SALAMAGA, A., 2013. Oligonema flavidum (Myxomycetes): a species new to Poland. Polish Botanical Journal, vol. 58, no. 2, pp. 747-749. http://dx.doi.org/10.2478/pbj-2013-0074.

SILVA, S.G. and BEZERRA, J.L., 2005. Ocorrência de Fuligo septica em alface e coentro de caboclo. Fitopatologia Brasileira, vol. 30, no. 4, pp. 439-439. http://dx.doi.org/10.1590/S010041582005000400024 .

SILVA, S.G., FERREIRA, I.C.M. and BITENCOURT, N.V., 2008. Novos hospedeiros de Fuligo septica no Maranhão. Summa
Phytopathologica, vol. 34, no. 1, pp. 439-439. http://dx.doi. org/10.1590/S0100-54052008000100025.

STEPHENSON, S.L., NOVOZHILOV, Y.K. and SCHNITTLER, M., 2001. Distribution and ecology of myxomycetes in high-latitude regions of the Northern Hemisphere. Journal of Biogeography, vol. 27, no. 3, pp. 741-754. http://dx.doi.org/10.1046/j.13652699.2000.00442.x.

TRIERVEILER-PEREIRA, L., BALTAZAR, J.M. and LOGUERCIOLEITE, C., 2008. Santa Catarina Island mangroves - First report of Myxomycetes on Avicennia schaueriana. Mycotaxon, vol. 103, pp. 145-152. 